\title{
A Foucauldian-Shakespearean Reading of the Twin Motifs of Love and Madness in Malcolm Bradbury's Eating People Is Wrong
}

Noureddine Friji*

English Language Institute, King Abdulaziz University, P. O. Box: 80200, Jeddah 21589, Kingdom of Saudi Arabia

Corresponding Author: Noureddine Friji, E-mail: nourddin_2000_friji@yahoo.com

\section{ARTICLE INFO}

Article history

Received: January 15, 2019

Accepted: April 28, 2019

Published: June 30, 2019

Volume: 10 Issue: 3

Advance access: May 2019

Conflicts of interest: None

Funding: None

Key words:

Hamlet,

Insane,

Madness,

Bradbury,

Foucault,

Psychiatrist

\begin{abstract}
Undertaking a careful examination of Malcolm Bradbury's academic novel Eating People Is Wrong (1959) by drawing on Michel Foucault's Madness and Civilization (1965) and on William Shakespeare's Hamlet, this paper's author argues that some individuals, capitalizing on the oldestablished connection between love and madness, choose to act insane to win others' sympathy and affections and that their strategy may not always live up to their expectations. The strategy itself, it will be clear, is a reflection of their social superiors' desire to punish or banish them, of the universal antipathy towards the mad, and of the proclivity for maltreating them. The author also aims to prove that madness is not always the inevitable result of unreciprocated love and that it may as well be brought about by a loveless life. The paper concludes that madness, be it real or sham, never ceases to preoccupy us and that no matter how hard we try to extend sympathy to the mad, they generally continue to occupy the bottom of the social hierarchy. In addition to the foregoing thematic pursuits, it is also hoped that the reader will be given a helpful insight into the academic novel subgenre, which deserves to gain more ascendancy in the literary scene.
\end{abstract}

\section{INTRODUCTION}

\section{General Background}

Doubt there is none that the academic scene is essentially associated with conferences, intellectual debate, research, publishing, and exams. Undeniably, however, it favours the proliferation of love relationships and trysts among its population. Malcolm Bradbury's Eating People Is Wrong grants centrality to the latter theme and adds salt and depth to it by yoking it to the classically interlinked themes of love and madness. The tragic character of the love story of a student called Louis Bates is conveyed through the novel's reference or allusion to Shakespeare's Hamlet, to Shakespearean characters like Macbeth (152) and Malvolio (270), and to Shakespearean settings (265). This serves to confirm how shadowy the borderland can be between comedy, towards which academic novels have a certifiable leaning, ${ }^{1}$ and tragedy, as presented by certain Elizabethan texts. In a 1983-profile by Ronald Hayman, Bradbury claims, "I have a real agony going on in my guts about what it is that we actually are as human beings. I do start out with a comic conception, but I must end up with a tragic one, because my subject is the classic one of what's happened to humanism" (qtd. in
Bradbry, "Malcolm" 26). In view of the above, Michel Foucault's exploration of the mistreatment of the mad in his Civilization and Madness may be considered the most suitable theoretical approach for investigating the twin motifs of love and madness in Bradbury's novel and for casting light on the injustices done to presumably mad people.

\section{Theoretical Background}

While taking a sweeping look at the diverse forms of the exploitation and ill-treatment of unprivileged people like lepers, vagabonds, criminals, beggars, and the poor, among others, Foucault reserves the bulk of his book for the investigation of the subjugation of the mad during the classical age, the period between the end of the sixteenth century and the eighteenth century. When leprosy receded into history at the end of the Middle Ages (3), he relates, people became obsessed with madness (7). As it gained hold on public imagination and a foothold in literature, Folly, which was on the hierarchy of vices alongside Idolatry, Despair, Avarice, Lust, Anger, Harshness, Discord, Rebellion, Inconstancy, Cowardice, and Pride, started to lead "the joyous throng of all human weaknesses." Medieval and Renaissance Europe, therefore, 
hastened to erect places of detention for madmen (8). Like other confined people, these victims lived in bad conditions as they were squeezed up against each other in overcrowded wards with dripping roofs, were chained to the walls, and were easy targets for rats' bites (70-71). The dangerous ones, on the other hand, were chained lest they should alarm or harm onlookers (72). The strict pedagogy and discipline imposed on the insane during the eighteenth century led to the emergence of the "theme of the animal-madman" (75) or the madman as "a beast of burden" (76).

As cities chose to deal with their own mentally deranged citizens only, foreign madmen roamed the countryside or were transported by ship from one town to another (Foucault 8) in what amounted to a symbolic quest for reason (9). Hence the bourgeoning popularity of the phenomenon of the Ship of Fools, "a strange 'drunken boat' that glides along the calm rivers of the Rhineland and the Flemish canals." The Narrenschiff, Foucault goes on, is "a literary composition, probably borrowed from the old Argonaut cycle, one of the great mythic themes recently revived and rejuvenated, acquiring an institutional aspect in the Burgundy Estates" (7). Notable among the texts tackling the theme of "dream fleet" and "romantic or satiric vessels" is Sebastian Brant's Narrenschiff (1494). ${ }^{2}$ Paradoxically, while the sea journey is generally associated with freedom, madmen were treated as prisoners aboard the sailing ships: "Confined on the ship, from which there is no escape the madman is delivered to the river with its thousand arms, the sea with its thousand roads, to the great uncertainty external to everything. He is a prisoner in the midst of what is the freest, the openest of routes: bound fast at the infinite crossroads" (11). ${ }^{3}$

Foucault splits madness into several categories, three of which are of direct relevance to this study. The first is madness by romantic identification. Inaugurated by Miguel de Cervantes's Don Quixote, it is premised on the assumption that the reader may identify with the literary model created by a certain author to such an extent that he or she adopts the theme of the "Ragged Knight" (29). Second, according to the category of madness of just punishment, the madman imagines himself being punished for a certain crime he has committed (30). Finally, an individual may run mad because of desperate passion, especially when he or she is disappointed in love. An excess of passion may even culminate in the lovers' death (30), as is the case with Shakespeare's Ophelia and King Lear and with Cervantes's protagonist in Don Quixote (31). ${ }^{4}$

Physicians in the classical age, Foucault goes on, devised a number of cures and methods to treat madness in the non-hospital domain. For instance, they utilized blood transfusion to destroy corruptions (163) and cure melancholy (162). It was also hoped that the fermentations accumulating in the body and bringing about madness could be dissolved through bitter products such as coffee, sea water (164), the quinine, soapy fruits (cherries, grapes, oranges, pears, fig), soluble tartar (165), and vinegar (166). Next, immersion was regarded as a helpful treatment because water was believed to be a symbol and a means of purification and to be an effective regulator, hence its association with ablution (16667 ) and hence the medieval habit of plunging madmen into the water (167). Finally, people were encouraged to exercise and travel in the belief that mobility and change of scenery restored vitality to the mind and the spirit (173) and curbed melancholy (174).

Finally, Foucault gives Philippe Pinel and Samuel Tuke, two renowned nineteenth-century psychiatrists, credit for the birth of the asylum (242-43). After visiting Bicêtre, Pinel urged that the prisoners be unchained and treated in a humane way (242). Similarly, Tuke insisted that the sick be treated respectfully and that the old tendency for highlighting their monstrous aspects only was far from fair (248). Effective observation, he observed, had to take into account the human and social aspects of the patient's personality and life (249).

\section{Literary Background}

Shakespeare's Hamlet provides classical literary illustration of the age-old correlation between madness and love. Ophelia, the girl Hamlet is besotted with, confides to Polonius, her father, also the King's counsellor, that Hamlet has "... of late made many tenders/Of his affection to me" (1.3.99$100)$; that "... he hath importuned me with love/In honourable fashion" (110-11); and that he "... hath given countenance to his speech, my lord,/With almost all the holy vows of heaven" (113-14). Her report soon assumes a sombre tone as it catches the strange changes affecting Hamlet's character and behaviour as a consequence of his passion. As she was sewing (2.1.77), she intimates, Hamlet made his appearance, giving every appearance of being distraught. Hence his "unbraced" doublet (78), his "fouled" stockings (79), his shaking knees (81), and his "piteous" look (82). Giving the impression that he has "been loosèd out of hell" (83), she goes on, he started speaking of "horrors" (84). Building on his daughter's account, Polonius decides:

This is the very ecstasy of love,

Whose violent property fordoes itself

And leads the will to desperate undertakings

As oft as any passion under heaven

That does afflict our natures... (102-06)

He also puts Hamlet's madness down to the fact that Ophelia has ignored his letters and refused to see him (Shak. 108-10), as per his [Polonius's] own instructions. He reiterates this point later while addressing the King:

... And then I prescripts gave her,

That she should lock herself from his resort,

Admit no messengers, receive no tokens.

Which done, she took the fruits of my advice,

And he, repellèd, a short tale to make,

Fell into a sadness, then into a fast,

Thence to a watch, thence into a weakness,

Thence to a lightness, and, by this declension,

Into the madness wherein now he raves

And all we mourn for. (2.2.142-51)

Polonius recalls that he himself was once the victim of "extremity for love" (Shak. 2.2.190) and keeps attributing Hamlet's "lunacy" (49) and grief to "neglected love" (3.1.181). He then urges the King to send him to England immediately "... or confine him where/Your wisdom best shall think" (187-88). The King, who is looking forward 
to getting away with his murder of Hamlet's father and to warding off the threat which a potentially revengeful Hamlet may pose to his throne, agrees to take measures to this effect: "It shall be so,/Madness in great ones must not unwatched go" (198-90). Echoing the classical-age belief that the sea and travelling can cure madness, he decides to send him to England immediately (163-70) in the hope that "... the seas, and countries different,/With variable objects, shall expel/This something-settled matter in his heart" (172-74). He later asks Rosencrantz and Guildenstern, Hamlet's childhood friends, to make haste and take Hamlet to England (3.3.1-4). "Arm you, I pray you, to this speedy voyage," he urges, "For we will fetters put about this fear,/Which now goes too free-footed" (24-26). His fears are not late in being confirmed. When Hamlet murders an eavesdropping Polonius (4.1.34), the King exclaims, "How dangerous it is that this man goes loose!" (4.3.2). Before long, he insists that his allegedly mad nephew be taken away at once because "[d]iseases desperate grown/By desperate appliance are relieved,/ Or not at all" (9-11). He also warns Hamlet that he will be sent to England "[w]ith fiery quickness..../The bark is ready and the wind at help" (42-43). As the latter departs, the King, speaking to himself, says:

Follow him at foot. Tempt him with speed aboard,

Delay it not. I'll have him hence tonight.

Away! For everything is sealed and done

That else leans on the affair. Pray you, make haste. (56-59)

The truth, however, is that Hamlet, having been informed by his father's ghost that his uncle and stepfather, Claudius, is the one who murdered his (Hamlet's) father, starts feigning madness in order to investigate the murder without arousing suspicion about his awareness of the truth. Early in the play, he intimates to his closest friend, Horatio, that he will "... put an antic disposition on" (Shak. 1.5.172). Later, he boasts that he has managed to deceive his mother and uncle into believing he is mad (2.2.274-75) and confides to Guildenstern that "I am but mad north-north-west. When the wind/is southerly, I know a hawk from a handsaw" (27778). The King, consumed with curiosity, essays to pierce the atmosphere of mystery and mystification hanging about his nephew's demeanour by asking Rosencrantz and Guildenstern to find out why his nephew "... puts on this confusion, Grating so harshly all his days of quiet/With turbulent and dangerous lunacy" (3.1.2-4). Guildenstern, however, admits that Hamlet's behaviour requires much digging below the surface:

Nor do we find him forward to be sounded,

But with a crafty madness keeps aloof

When we would bring him on to some confession

Of his true state. (6-9)

In addition to love and madness, the theme of suicide plays a pivotal role in the play. Grieving for his father, and disappointed about his mother's marriage to his uncle, Hamlet wishes he would die (Shak.1.2.333-34) and intimates that if suicide were not forbidden by God he would immediately put an end to his life (335-36). He picks up the thread of this idea in his famous "To be, or not to be" soliloquy, where he wonders whether it is better to die and be relieved of the misfortunes he is suffering or to live on and endure his misery as no one knows what is lying ahead for them after death (3.1.80-84). Notwithstanding his anguish, he does not commit suicide in the long run. Having initially displayed hesitation about avenging his father's murder and conceded that "... conscience does make cowards of us all" (83), he declares, upon returning to Denmark from his English exile, that "[t]he readiness is all" (7.2.216). This explains why he soon wounds the King with a poisoned sword (316) and forces him to drink from a poisoned cup (319) before he, too, dies from the wound he receives from Laertes's poisoned sword (321). On the other hand, a frail and mad Ophelia, having lost hope of getting Hamlet to return her love, and feeling wretched subsequent to the loss of her father, succumbs to the suicide temptation by drowning herself in a brook (4.7.66-75). Laertes, however, rebuts the allegation and insists that his sister be given a proper religious burial (5.1.227-31)

\section{Literature Review}

The causal relationship between love and madness boasts an immemorial antiquity. Little marvel that it has been researched extensively (Brewer, Weaver, Hood, Khayrallah, etc.). It suffices, however, to take two examples. Brewer looks at the spread of real and fictional murders and attempted suicides, or rather "crimes of passion" (2), caused by love and subsequent madness in the eighteenth century and records people's reactions to these events in the Victorian and Romantic eras as well as in the twentieth century. Weaver, on the other hand, attends to the fortunes of "three unhappy lovers" in Ariosto Ludovico's sixteenth-century chivalric epic Orlando Furioso, namely Orlando, Rodomonte, and Bardamonte. Focusing on the use of the interlacement technique, she notes that these lovers "are portrayed afterwards as mad, albeit to a different degree, and the particular madness of each is seen as a development of his or her love" (127). She then goes on to detail the manifestations of the three characters' madness and the other characters' reactions to it.

The present article's aim is to make a valuable contribution to the field of study under consideration while lending it critical freshness and novelty not only by detecting and inspecting the intertextual aspects of its content and intent but also by bringing it to bear on the academic novel subgenre, whose characters, communing and communicating in an enclosed milieu, tend to fall in and out of love more frequently than their counterparts in other literary subgenres. The article's writer first seeks to spot out the signs of Louis Bates's madness, after which he tries to demonstrate that Bates is only acting insane to worm himself into the affections of the postgraduate student Emma Fielding, that the character who ultimately runs mad is the university professor Stuart Treece, and that his madness is due to his empty and loveless life rather than to unreturned love.

\section{ANALYSIS}

\section{Bates Furioso}

As is the case with Hamlet, close inspection of Bates's passion for Emma, who is, significantly enough, doing post- 
graduate research on fish imagery in Shakespeare, reveals that unrequited love, or "desperate passion," as Foucault calls it, is a crucial factor in bringing about madness. Indeed, he once considers the idea of surrendering to "mad passion" and kissing Emma's elbow (Bradbury, Eating 87; emphasis added). The latter later complains to Treece that her suitor has sent her two letters in which he "confessed his mad passion and sought to drag her some way towards the altar" (94; emphasis added). ${ }^{5}$ Bates, the narrator writes, "had come to a kind of desperation" (emphasis added). This "was a new Louis," the narrator goes on, "an extravagant, passionate Louis, doing new things, thinking new thoughts. Each morning he gazed at the solemn, hollow face that peered back at him from the mirror, smiled at it, teased and tempted it, said to it, 'Emma, Emma, Emma." " (128). Before long, speaking "despairingly," the lovelorn student tries to assure Emma that they can make each other happy and swears eternal constancy to her (129; emphasis added). Having "cavorted with love," he not only makes his love for her public knowledge $(137,165)$ but also keeps combing the University in search of her (127). Visiting her at the Bishops', he laments that he can neither eat nor work because of her (128) and reminds her that he is a human being who needs love as much as everyone else (129). He later enthuses, "I know I'm not very good with women; I'm no Don Juan. My intentions were honourable; I'm not doing this for fun, you know" (133). His misery is not limited to lack of appetite for food and work. Attending Treece's tutorial, he blames his poor performance in the exam on Emma in the presence of the other two students, Sykes and Cocoran (165).

Like Shakespeare's Ophelia, an unresponsive Emma kindles her suitor's romantic flame and prolongs his agony by assuming the role of an elusive maiden throughout the novel, a role possibly bequeathed to her by the notorious Angelica who causes Orlando, Charlemagne's renowned knight, to lose his mind because of love. ${ }^{6}$ As Treece's party comes to an end and the guests start dispersing, Bates, wallowing in the throes of passion, looks for Emma everywhere, but she "seemed to have disappeared completely" (Bradbury, Eating 89). Running along the road after her as she rides away, her bicycle's red tail light is "gone from view" in "another moment." Only when Cocoran refuses to lend him his bike does Bates decide to give up the chase (90). When Emma rebukes him for having behaved "absurdly" at the party (156), he decides to provoke her jealousy by talking to one of the female guests. Meanwhile, she "had slipped away," and he finds her in the garden with a novelist called Walter Oliver (158). Soon later, as he finishes talking to the music band in a bar, he realises that "there was nothing to be seen of Emma," who has just finished dancing with him. Having failed to locate her, he sends her a letter, inviting her to the cinema and explaining how difficult it is for him to forget her (196). This love declaration, however, only serves to foster her haughtiness and naughtiness, as it were.

Emma's cruelty to Bates is best captured through the narrator's invocation of the famous fairy La Belle Dame Sans Merci (The Beautiful Lady without Mercy), a character immortalized by John Keats's ballad of that title. Bringing up the subject of Bates and Eborebelosa with Treece, she wonders, “Am I some sort of Belle Dame Sans Merci, who tempts people into love without having the least capacity to respond with any?" (Bradbury, Eating 95). On another occasion, she greets Bates's avowal of love with "pity and a scrap of distaste" (170) and informs him that although she respects him (194), she can offer him nothing but friendship as she hates to play the role of a "Belle Dame Sans Merci, who takes love without giving it" (195). ${ }^{7}$ Although Emma generally denies having anything in common with the aforementioned fairy, her behaviour argues to the contrary. Hence the narrator's claim that she "was a minx" because she "tortured him [Bates] and made him perpetually miserable" (266) and Mirabelle's assertion that Emma is "not our sort" and that she is "clever with men" (137).

Bates's madness reaches a peak on the occasion of a boat trip he takes with Emma. Being sick and tired of his emotional outpourings, and having decided that he is eccentric, Emma, echoing both Foucault's claim that mobility and change of scenery can curb melancholy and Claudius's decision to send an allegedly mad or melancholic Hamlet to England to help him recover his wits, suggests that they "go somewhere more. Elizabethan" (Bradbury, Eating 265). Bates, however, continues to assume the role of the besotted lover. As they walk towards the river, he holds her arm and carries her basket, explaining "in her ear how he was adapting Andalusian guitar music for the flageolet. and how he wished he had his flageolet today so that they could have gone gaily downstream playing Handel's Royal Water Music." When he gets to the boathouse, he is warned that the river is too crowded for punting and he, therefore, chooses a canoe, "a mistake on his part, he realised at once, for if punts are amorous, canoes are chaste, and all he could get for his hour was a view of Emma's back" (266). The implication, of course, is that she has turned her back on him both literally and figuratively. No wonder that he and his companion are compared to "passengers in a bus, both facing the same way" (269). Meanwhile, the beauty of the day, "one of those fresh days of spring when the thin sun lights up the dulled grasses and brittle hedges, bringing out birds and the early buds" (262), together with the beautiful scene and the sense of freedom and peace generated by "the full, still water" as it "slid gently over the weir," fire Bates with passion for his uncaring companion (267).

However, being crippled by a feeling of cowardice and hesitation, he identifies with Shakespeare's hesitant Hamlet, enacting what Foucault calls madness by romantic identification. Then, he decides that even Hamlet is a man of action, hence the murders he commits. His hesitation is such that he cannot decide whether to opt for marriage, which he does not consider a happy end of a relationship (Bradbury, Eating 267) "but the sad beginning of a sentence," or whether to limit himself to love, "a sweaty Turkish bath of feeling" (268). ${ }^{8}$ Tapping Emma on the shoulder in a vain attempt to get her to look at him, he enthuses that he loves her and spices his emotional outburst with a passage from the German philosopher Nietzsche, ${ }^{9}$ with whom he also seems to identify. However, he draws a blank, as Emma does not understand German. Equally fruitless is his request that she submit her Virtue to his Pride lest she should "hamper his sexual development, do 
him psychological harm, corrupt his future sex life" (268). As he stands "in wild excitement" and resumes addressing her in German, he falls into the river and disappears under the water, possibly in the hope of recovering his sanity as people in the classical age would claim. His terrified companion hastens to drag him out, gives him artificial respiration, wraps him in his overcoat, and paddles him back to Stratford (269), Shakespeare's hometown. Meanwhile, confirming his being a latter-day passenger aboard the notorious ship of fools, and echoing Walter Oliver's earlier claim that he (Bates) is "a fool" (214), Bates cries, "I'm such a fool, such a fool" (269). Immediately after, Treece rushes him to hospital, although he insists that he see the play scheduled at the theatre (270).

When Emma visits him in hospital, Bates launches into a prolonged talk about his being unlucky with respect to love and women (Bradbury, Eating 285), but she decides that he refuses to confront the truth and fears that he is "trying to work her into some position in which they were firmly entangled, some vague emotional complex on which he could build." Taking her cruelty to extremes, she reveals that she has an affair with Treece. "It was an absurd cruelty," the narrator states, "but then someone had to pay for the moral damage caused, and who could it be but Louis?" (286). Having plumbed the depths of despair, the latter, taking his cue from Ophelia this time, takes a big dose of aspirin to take his own life (287). ${ }^{10}$ Once again, echoing Foucault's assertion that the relationship between patients and psychiatrists took on a more humane aspect as of the nineteenth century, the German psychiatrist who visits Bates in the company of a policeman tries to allay his fear by introducing himself as a friend and by assuring him that his role is to help him (287).

At last, Bates is committed to a mental asylum, where the spectre of his madness and menace is laid to a troubled rest, hence a fearful and tearful Emma's claim that he may be "locked away in there for ever." Treece hopes that they will soon get him out but, possibly feeling relieved of Bates's rivalry with him for Emma's favour and of the threat his madness may pose, he adds, in the same breath, that it is better for him to stay in the mental asylum to avoid being tried for attempted suicide. On the other hand, Emma, her sympathy for Bates notwithstanding, does not offer to get him out and, instead, expresses her shock at the fact that he may be punished by law (Bradbury, Eating 288). She then admits having brought all this trouble on him, that she respects him, and that she cannot, however, return his love. Finally, she dismisses him as "the whipping-boy" (289), inviting the arguable suggestion that the novel could also be entitled Beating People Is Wrong.

\section{DISCUSSION}

\section{Feigned Madness}

When all is said and done, I suggest that Bates, taking his cue from Hamlet, does not run mad as the other characters are led to believe and that he purposely collapses the distinction between reason and madness in order to win the sympathy of an allegedly "sensitive and mature" Emma, who is "careful of the feelings of others" (Bradbury, Eating 67), after failing to win it through his recurrent complaints about his poor health $(130,260,261)$ and through his outpourings of love. There is enough solid textual evidence to corroborate this surmise. Dilating on Bates's misery and despair, the narrator reports that he "had, somehow, to act" (128), after which he invites us to witness his avowal of love to Emma (128-34). I contend, however, that the word act here may not only be interpreted as "to do something for a particular purpose or in order to deal with a situation" ("Act" 1) but also as "to pretend by your behaviour to be a particular type of person" ("Act" 3). This is best captured through the question the psychiatrist puts to Bates: "Did you want to kill yourself or just make a big demonstration?” (287).

It may also be legitimate to propose, once more, that Bates is enacting another denotation of the term act, namely "to perform a part in a play or film/movie" ("Act" 4). By so doing, of course, he lends more credibility to his sham madness with an eye to attaining his goal. His identification with Hamlet, as seen above, explains why he agrees to join Emma when she suggests that they "go somewhere more Elizabethan" on the occasion of the trip to Stratford. The narrator seems to hint that Bates cannot, however, be a replica of Hamlet or of any Shakespearean character at that by reporting, "Louis banged his head on a low beam; he really was a modern man, and Elizabethan houses were built for rather smaller people" (Bradbury, Eating 265). Nevertheless, this does not detract from the significance of this desperate suitor's attempt to establish a textual identity for himself and to achieve his goal by adopting previous devious schemes. Significantly, it is also obliquely revealed that he bears some resemblance to another Shakespearian character other than Hamlet, namely Malvolio, one of the leading characters in Twelfth Night. Indeed, after the river accident, Emma, sitting at the theatre and "watching poor Malvolio, so serious and resplendent in his virtue, duped and outwitted, thought of Louis and tried not to feel angry that his fate had got so aggravatingly mixed up with hers" (270). The similarity is enhanced by the fact that Malvolio is also believed to be "hoodwinked into performing lunacy" as the characters Maria and Toby join forces to "create the impression that Malvolio has gone utterly mad" (Kamps 231).

Bates seems to have done some rehearsal before assuming these roles, in a manner of speaking. After attending Treece's party and failing to talk to Emma, who has ridden home, he "tasted the role [of the desperate lover] for a moment or two" (Bradbury, Eating 91). In fact, he assumes the role so well that he assumes that he can turn into a handsome man. "When he looked into the mirror each morning," we are told, "he half expected to find, one morning, a different face there, the face of Louis the lover, Louis the seducer, the fresh, cherubic face of a young man with sparkling eyes and shining teeth" (127-28). ${ }^{11}$ To his dismay, however, the same "long and gaunt" face faces him (128).

\section{Treece's Madness}

Having sought to invalidate the assumption that Bates is mad, one is tempted to suggest that the character who finish- 
es up being mad as a result of an emotional void is, contrary to all expectations, Treece, Emma's sexual partner and the most likely candidate for her heart and hand throughout the novel. It is small wonder the office he occupies was previously a gloomy and dark padded cell (Bradbury, Eating 31). As another victim rather than a victor, he is not "the prime mover in the affair" he has with the latter-day Belle Dame Sans Merci since "she gave ground only when she wished, with him following, having no choice, possessing nothing and simply being possessed" (190). When he retires to his room in the wake of a poetry conference, he

felt himself assailed by a violent unrest, a positive physical discomfort, a sense of loss, though he could not say what was lost or when the feeling came. It was a sense of having uprooted himself and cut himself from any vigorous way of life, this, and an oppressive loneliness. He realized that the last few days and weeks had passed in a kind of arduous, strained state, in a painful intensity; he could scarcely remember what he had done over these weeks. He felt challenged; he needed somewhere to turn, someone to love. (251)

Examining his face in the mirror, he decides that the changes affecting it puffed eyes and drier and greyer hair confirm how sick he is and that "the illness, if not physical, was then mental." It also dawns on him that his depression is "psychotic." Calling to mind the category of madness of just punishment expounded by Foucault, he feels he is the victim of "a kind of paranoic depression, in which the universe seemed to him unerringly hostile" and in which he feels that he is separate from other people, that he is unwanted everywhere, and that people and fate "are conspiring against him and working towards his downfall” (Bradbury, Eating 252). Overwhelmed by despair, he intimates to Emma, "I suppose I always wanted to settle down, but just never knew how you did it... Not to have love - that's the most terrible thing. Not to be loved by anyone, or to have any love of your own and spend it in the world. I mean the love we give to women is part of the force of passion we have for the world" (253).

Lying in a barred crib bed in hospital, he grows more aware of his "psychotic state" (Bradbury, Eating 272) and "his own depressed mind" (280). Once again, alluding to madness of just punishment, he complains to his doctor, "And then I have these periods of completely ungovernable depression in which I scarcely dare out of the house for fear that God will come down and hit me. I mean, it's completely manic. I feel as though people I don't know will come up to me in the street and kick me in the groin" (271). The doctor, having established that his patient is mentally disturbed, objects to his request that he be allowed to leave the hospital to teach his evening classes. "You must be crazy," he rebukes, "You walk in here and talk about God and you ought to be lying flat on your back and not moving" (272). Building on Foucault's claim that blood transfusion helps destroy corruptions and cure melancholy, we may interpret the doctor's decision to give Treece blood (279) as further testimony to the latter's disturbed mental state.

Additionally, the fact that the hospital is described as an old and "unpleasant building" with "Victorian windows and dark corners and mass of dirty ironwork" (Bradbury, Eating
272) brings to mind the derelict confinement houses mentioned by Foucault. Significantly, it is the very building in which Bates is hospitalized before being taken to a mental asylum and where the psychiatrist visits him, demonstrating how thin the line between madness and other diseases is. Equally revealing is the fact that the patients behave like confinement houses' internees. As a consequence, Treece has a wakeful night because some of them keep vomiting by his ear while others tend "to ask him to make their wills, fetch them a bottle, write to their relatives, shave off their whiskers, [and] hold bowls while they were sick into them." Being a firm believer in "civilized and respectful contacts, deep personal relationships, and integrity of motive, recognition of the individuality of persons," the ailed teacher feels wretched as a result of being deprived of his society and of living in an environment where only "the preservation of life" and physical matters matter (279). ${ }^{12}$

Unsurprisingly, he feels as selfish and lonely as a passenger "on shipboard" (Bradbury, Eating 278). This again brings us back to the suffering experienced by the passengers aboard the Ship of Fools and invites the conjecture that Treece has joined Bates on board the ill-fated ship, if only figuratively. When Emma visits him in hospital and blames him for having kept his illness secret from her, he tries to win her sympathy while pretending otherwise: “One can't use one's illness as a kind of moral lever, and if I had told you, that's what I would have done. I would have said, 'Look, I need looking after. Won't you marry me?' I want to say that now. You see how much I need you. I have no one. I hate to be left alone. I feel so depressed. I think I have a fragmented gestalt" (282). To his disappointment, his interlocutor confirms her striking similarity to La Belle Dame Sans Merci: 'I've been terrible to you. Can one lead a good life in this world? I mean, without doing too much harm, and retiring too much out of it, so that people you are involved with suffer?" (283). Although she agrees to visit him again, at his request, their relationship, one inclines to think, is definitely a thing of the past. As she earlier turns her back on Bates as she turns her back to him during the river trip, so she now walks out on Treece as she walks out of his room. Meanwhile, giving every impression of being a confined madman and of being reconciled to his fate, the latter "lay there in his bed, and felt as though this would be his condition for evermore, and that from this he would never, never escape" (290).

\section{CONCLUSION}

Drawing inspiration from Michel Foucault's Madness and Civilization to investigate the curious resemblance the protagonist Louis Bates bears to his literary progenitor, Hamlet, this essay has essayed to demonstrate that madmen have always been relegated to the margins of society. It has also been argued that the well-worn and oft-told madness motif can spill over into the field of love relationships and that affected madness, which owes its genesis to Hamlet, can be adopted by socially unwelcome people like Bates to win and savour the favour of liberal characters like Emma Fielding. On the other hand, it has been demonstrated that an emotional void can culminate in madness. 
With regard to style, Bradbury's exploration of the theme of madness through recourse to an Elizabethan literary precedent makes his novel converge with a time-honoured literary tradition which treats love and madness as two sides of the same coin. Hence its success in plying a middle ground between tragedy and comedy. It is worth adding that while hugging the shore of mundane preoccupations, Bradbury's novel continues to sail under the flag of the modern university and its associated scholarly pursuits and, by so doing, it creates recognizable, knowledgeable, and acknowledgeable academic characters.

\section{END NOTES}

1 Kingsley Amis's Lucky Jim (1954) is credited with instigating the comic character of the academic novel (Lodge, "Lucky" 86), which is ascribed to the following factors:

The academic institution is a small world, a microcosm of society as a whole, in which themes like the operation of power, ambition, and sexual desire, can be studied in a comic and satiric rather than tragic manner. The fact that university staff are theoretically committed to the preservation of high culture, and the pursuit of truth, but are fallible human beings with ordinary human weaknesses and perhaps more than usual eccentricities, makes a good setting for comic and satirical writing. (Lodge, "Interview")

2 Brant's Narrenschiff, or The Ship of Fools, contains 112 chapters, each of which attends to a different cast of fools. At the same time, each fool in the book is depicted in a woodcut. Chapter 108, "The Schluraffen Ship," may be considered the most informative one with respect to the theme of the ship of fools and the misery its passengers experience. The latter are determined to proceed with their sea journey (350) regardless of the threats posed to their lives by beasts and fish (351) and of potential storms and shipwreck (353). They find consolation and historical precedent for their plight in the myth of the legendary Homeric character Ulysses, who faces many dangers while sailing, weathers a shipwreck which claims his companions' lives, and finally manages to swim to the shore (351-53). Their fate having been sealed, Brant's passengers selflessly warn sane people against undertaking the same voyage:

Oh stay at home, ye men of sense

And let our fate a lesson be:

Don't go to sea with levity,

Or else with winds you'll have a fray

As did Ulysses every day. (354)

3 Prasad illustrates the time-honoured association between the sea and freedom in Eugene O'Neill's works $(19,23,87)$. Moreover, Auden, examining the privilege accorded to the sea in Romantic literature, writes, "As places of freedom and solitude the sea and the desert are symbolically the same. In other respects, however, they are opposites. For example the desert is the dried-up place i.e., the place where life has ended, the Omega of the temporal existence... The sea, on the other hand, is the Alpha of existence, the symbol of potentiality" (qtd. in John 124). In Byron's Childe Harold's Pilgrimage, too, the speaker considers the "boundless, endless and sublime" ocean the "glorious mirror" of "the Almighty's form" and "the image of Eternity" (252; canto 4, st. CLXXXIII). He then considers himself the "child" of the sea. It is small wonder that he "trusted to thy billows far and near,/And laid my hand upon thy mane - as I do here" (CLXXXIV).

4 For an illuminating insight into the madness motif in Don Quixote, see Bauer.

5 This brings us to Lakoff and Johnson's exploration of the indissoluble link between love and madness and to their inclusion of a number of expressions under the metaphor LOVE IS MADNESS, such as "I'm crazy about her. She drives me out of my mind. He constantly raves about her. He's gone mad over her. I'm just wild about Harry. I'm insane about her" (49).

6 For a faithful rendering of Ludovico Ariosto's Orlando Furioso, see Bulfinch.

7 Keats's "La Belle Dame Sans Merci" addresses the pains attendant on love by depicting the misery of a knight into whom the speaker runs on a cold day, in a gloomy landscape where "[t]he sedge has withered from the Lake/And no birds sing." The "haggard" and "woebegone" knight confides that he was irresistibly drawn to "a beautiful" "faery's child" he met by chance "in the Meads"; that he made her present of "garlands" and "bracelets"; that she seemed besotted with whim; that he set her on his steed and roamed with her for a whole day while she sang a fairy song and admitted how greatly she loved him (7); that she took him to her "elfin grot," where "she wept and sigh'd full sore," after which he kissed her "wild, wild eyes" and she lulled him to sleep; that "pale" kings, princes, and warriors warned him in a dream, ". La belle dame sans merci/Thee hath in thrall"; and, finally, that he woke up to find himself on "the cold hill's side," where he is now wandering and wondering "[a]lone and palely loitering" (8).

8 Similarly, while admitting that he was once in love with Ophelia (Shak. 3.1.115), Hamlet urges her to go to a nunnery and to marry a fool since wise men like him are wary of women (137-40). He also vows never to bring up the subject of marriage and advises single people not to get married (148-50).

9 Nietzsche himself is alleged to have become insane in 1889 (Kaufmann 22), but it is not logical to dismiss his books as "the fabrications of a madman" (70).

10 Actually, Bates has a natural leaning towards suicide. He intimates to Emma that Mirabelle does not want him to come to her party because while attending a party of hers once, he cheated at a game called "Murder" by opting for suicide (Bradbury, Eating 139). In a similar vein, after Emma rejects him, he walks under damp trees, "perversely trying to catch pneumonia, bursting with chagrin..." (135).

11 In McCarthy's Groves of the Academe (1951), Henry Mulcahy, an instructor of literature at Jocelyn College, Jocelyn, Pennsylvania, having learnt that his contract will not be renewed, decides to act insane: 
In order to win, it would be necessary to shut his mind even to its own settled purpose, to be furious, voluble, contradictory, incapable of "listening to reason." What was required, in a word, was just the obstinate feigned madness of Hamlet's, the rejection of all outcomes and explanations, the determination to make trouble, to be inconvenient, obtrusive to the general weal, like a side-walk demonstrator who declines to "move on" when the word from above is given. (10)

In a similar vein, Henry Beamish, one of the chief characters in Malcolm Bradbury's The History Man (1975), having cut his arm on one of Howard Kirk's windows during a party (93), ascribes the accident to the fact he stepped on a piece of glass, slipped, and had to shove his hand through the window in order to stop himself from falling (167). A teacher called Flora Beniform, however, presumes that Beamish's window wound may not have been an accident at all because there was no ice at Kirk's party (179). "When a man who publishes, like Henry, chooses his left arm," she claims, "you can be sure he has hopes of going on writing with his right" (118). His wound is, in other words, a result of "a minimal suicide attempt" meant to draw his friends' attention to him (119) and to gain his estranged wife's sympathy (180), a mere "act of anger and despair. An appeal," and a mere act of acting. Hence her assertion that suicide is "the traditional way of nullifying oneself as an actor," as is the case with Hamlet (117).

12 This should not surprise Treece, however. When Viola Masefield, an Elizabethan drama teacher, insists that Bates be dismissed from the University and be taken somewhere where he can be cared for, Treece, conjuring up Foucault's detailed account of the terrible life conditions in confinement houses, objects, "But do you know what mental hospitals are like? Do you suppose he's a severe case? It seems to me more than likely that a mental hospital would send him over the edge" (Bradbury, Eating 170).

\section{REFERENCES}

“Act." Def. 1. Oxford Advanced Learner's Dictionary. $8^{\text {th }}$ ed., Oxford UP, 2019.

“Act." Def. 3. Oxford Advanced Learner's Dictionary. $8^{\text {th }}$ ed., Oxford UP, 2019.

“Act." Def. 4. Oxford Advanced Learner's Dictionary. $8^{\text {th }}$ ed., Oxford UP, 2019.

Bauer, Rachel Noël. "Madness and Laughter: Cervantes's Comic Fools in Don Quixote.” Diss. Vanderbilt U, 2007.
Bradbury, Malcolm. Eating People Is Wrong. 1959. Acad. Chicago, 2005.

---. The History Man. 1975. Arrow, 1981.

--- "Malcolm Bradbury." Interview by John Haffenden. Novelists in Interview. By Haffenden. Methuen, 1985, pp. 25-56.

Brant, Sebastian. The Ship of Fools. Translated by Edwin H. Zeydel. 1944. Dover, 1962.

Brewer, John. A Sentimental Murder: Love and Madness in the Eighteenth Century. Farrar, Straus and Giroux, 2004.

Bulfinch, Thomas. Bulfinch's Mythology: The Age of Chivalry and the Legends of Charlemagne; or, Romance of the Middle Ages. 1858-63. New Amer. Lib., 1962.

Byron, George Gordon, Lord. Childe Harold's Pilgrimage. Floating, 2009.

Foucault, Michel. Madness and Civilization: A History of Insanity in the Age of Reason. Translated by Richard Howard. 1965. Vintage, 1988.

Hood, Gwenyth E. "Medieval Love-Madness and Divine Love." Mythlore 61 (1990): 20-28.

John, S. Beynon. "Image and Symbol in the Work of Albert Camus." Albert Camus, edited by Harold Bloom. Chelsea, 2003, pp. 113-28. Bloom's Biocritiques.

Kamps, Ivo. "Madness and Social Mobility in Twelfth Night." Twelfth Night: New Critical Essays, edited by James Schiffer. Routledge, 2011, pp. 229-43.

Kaufmann, Walter. Nietzsche: Philosopher, Psychologist, Antichrist. $4^{\text {th }}$ ed. 1950. Princeton U P, 1974.

Keats, John. "La Belle Dame Sans Merci." The Best John Keats Poems. Creator Space, 2013, pp. 7-8.

Khayrallah, As'ad E. Love, Madness and Poetry: An Interpretation of the Majnun Legend. Princeton UP, 1971.

Lakoff, George, and Mark Johnson. Metaphors We Live By. 1980. Afterword. Lakoff and Johnson. U of Chicago P, 2003.

Lodge, David. Interview by Mark Thwaite. Book Depository Interviews. 9 June 2009. n. pag. www.readysteadybook. co.uk/Blog.aspx?permalink=20090619091930. Accessed 17 Aug. 2018.

---. "Lucky Jim Revisited." The Practice of Writing. By Lodge. 1996. Penguin, 1997, pp. 85-97.

McCarthy, Mary. The Groves of Academe. 1951. New York: Harcourt, 1992.

Prasad, Hari Mohan. The Dramatic Art of Eugene O'Neill. Associated, 1983.

Shakespeare, William. Hamlet. Penguin, 1980.

Weaver, Elissa. "A Reading of the Interlaced Plot of the Orlando furioso: Three Cases of Love Madness." Ariosto Today: Contemporary Perspectives, edited by Massimo Ciavolella, et. al., U of Toronto P, 2003, pp. 126-40. 